\title{
KLASIFIKASI PETROFISIKA TIPE BATUAN UNTUK MEMPREDIKSI KUALITAS RESERVOAR PASIR SERPIHAN PADA FORMASI TALANG AKAR, CEKUNGAN ONWJ
}

\author{
Feni Priyanka $^{* 1}$, Bagus S. Mulyatno ${ }^{1}$, Riezal Ariffiandhany ${ }^{2}$ \\ ${ }^{1}$ Teknik Geofisika, Universitas Lampung \\ Jl. Prof. Dr. SumantriBrojonegoro No.1 BandarLampung 35145 \\ ${ }^{2}$ PT PHE ONWJ \\ Jurusan Teknik Geofisika, FT UNILA \\ e-mail: *Ifenigeophysical@gmail.com
}

\begin{abstract}
ABSTRAK
Hidrokarbon terakumulasi pada sebuah reservoar, reservoar memiliki banyak jenis tergantung pada kondisi geologi dan mineral penyusunnya. Pada Cekungan ONWJ, Sub-Cekungan Arjuna, Formasi Talang Akar merupakan jenis reservoar pasir serpihan. Hadirnya lempung dalam sebuah reservoar akan menurunkan nilai resistivitas dan menaikkan nilai saturasi, sehingga dibutuhkan analisis multimineral dan klasifikasi kualitas dari reservoar pasir serpihan. Di dalam penelitian ini, properti fisika (porositas, permeabilitas, Rw, dan saturasi) dan kualitas reservoar dapat diidentifikasi melalui analisis petrofisika dengan memanfaatkan data log dan analisis core, tipe batuan diprediksi melalui salah satu metode (antara R35 Winland dan HFU). Dalam penelitian ini data yang digunakan terdiri dari 5 sumur (IX-A1, IX-13, IX-4, IX-7 dan IX-8) dan ditemukan 8 zona hidrokarbon, 6 diantaranya sesuai dengan data DST (drill steam test), dan metode rocktype yang cocok digunakan yaitu metode HFU (hydraulic flow unit) karena koefisien korelasi antara porositas dan permeabilitas menunjukkan nilai $>0.75$, dan berdasarkan perhitungan diperoleh 8 tipe batuan, dimana dominasi tipe batuannya adalah jenis 12 dengan ukuran pori antara 5-10 mikron, tipe batuan reservoar pada penelitian ini termasuk ke dalam lithofacies Distributary channel dan sand mouth bar. Dengan mengetahui nilai properti petrofisika, maka dapat mengetahui reservoar performa dan menentukan zona yang layak untuk diproduksi maupun tidak, dengan menggunakan kurva SMLP (Stratigraphic Modified Lorenz Plot).
\end{abstract}

\begin{abstract}
Hydrocarbons were accumulated in reservoir, the reservoir has a lot of types depending on the geological conditions and the constituent mineral. In ONWJ basins, sub-basins Arjuna, Talang Akar Formation is sand splintersreservoir type. The presence of clay in a reservoir will reduce the resistivity and increase thesaturation, so it takes a multimineral analysis and the reservoir qualityclassification. In this study, physical properties (porosity, permeability, Rw, and saturation) and the quality of the reservoir can be identified through petrophysical analysis by utilizing log data and core analysis, and the rocktypeprediction(using R35 Winland or HFU method). In this study 5 wells (IX-A1, IX-13, IX-4, IX-7 and IX-8)used and found eight hydrocarbon zones, 6 are validated by the DST (drill steam test)data, androck type method that suitable is the method of HFU (hydraulic flow units) due to the coefficient of correlation between porosity and permeability shows a value of $>$ 0.75 , based on the calculations, the eight types of rock is conclude, where the dominance of the rock typeis the type 12 with a pore size between 5-10 microns, type reservoir rocks in this study belong to the lithofacies distributary channel and mouthbar sand. By knowing the petrophysical property values, it can determine reservoir productivity and determine the zone eligible to be produced or not, by using curve SMLP (Stratigraphic Modified Lorenz Plot).
\end{abstract}

Keywords - Rock type, kurva SMLP, multimineral, lithofacies 


\section{PENDAHULUAN}

Hidrokarbon terakumulasi dalam sebuah wadah yang dikenal sebagai reservoar, kondisi reservoar tiap lapangan memiliki sifat fisik (porositas, pemeabilitas, saturasi) dan karakteristik yang berbeda, bahkan dalam satu sumur dengan kedalaman berbeda akan menunjukkan sifat fisik yang berbedabeda, tergantung pada sejarah pembentukan dan komposisi mineral penyusun tiap formasi. Jenis formasi maupun reservoar bergantung pada komposisi mineral penyusunnya.

Jika tidak terdapat penyusun berupa mineral clay (lempung), maka akan menunjukkan formasi bersih (clean sand), namun sebaliknya jika semakin banyak kandungan mineral lempungpada suatu reservoar, maka reservoar tersebut akan dipengaruhi oleh mineral lempung dan formasi tersebut menjadi shaly-sand (pasir serpihan). Pada Cekungan Jawa Barat Utara, Sub-Cekungan Arjuna, tepatnya pada Formasi Talang Akar, merupakan salah satu reservoar pasir serpihan dengan litologi dominan berupa batuan pasir, serpih dan juga batubara delta, efek kehadiran mineral serpih maupun lempung akan menurunkan produktifitas hidrokarbon. Sehingga, efek dari kehadiran mineral tersebut harus diperhitungkan dalam proses analisis petrofisika reservoar pasir serpihan.Proses interpretasi pada reservoar pasir serpihan memiliki tantangan dan kesulitan tersendiri, hal ini karena banyaknya keragaman litologi dan kondisi geologi.

Maka, diperlukan metode analisis yang sesuai dan dapat memperhitungkan efek kehadiran mineral lempung.
Menurut Herdiansyah (2016) kehadiran mineral lempung akan mengakibatkan kesalahan dalam interpretasi terutama dalam pembacaan resistivitas dan memengaruhi harga saturasi air. Dalam petrofisika terdapat suatu metode perhitungan properti fisika batuan (porositas, permeabilitas, saturasi, resistivitas) yang dapat melakukan perhitungan efek kehadiran mineral lempung maupun shale. Metode tersebut adalah multimineral analisis, metode ini sangat bergantung pada jumlah mineral yang ada dalam suatu reservoar, sehingga efek kehadiran mineral lempung sangat diperhitungkan dalam perhitungan properti fisika batuan.

Selain itu, karena terdapat keragaman litologi dalam reservoar pasir serpihan, maka dibutuhkan metode yang dapat mengelompokkan reservoar berdasarkan kualitas maupun tingkat produktifitasnya yang ditunjukan dengan kualitas aliran fluida maupun kemampuan menampung fluida hidrokarbon. Melalui data core dan data $\log$, pengelompokan kualitas reservoir pasir serpihan dapat dilakukan menggunakan pendekatan petrofisika metode R35 Winland dan metode HFU (Hydraulic Flow Unit). Kedua metode ini merupakan metode yang memanfaatkan perhitungan berdasarkan data porositas dan permeabilitas core dan juga dapat digunakan dalam menghitung nilai permeabilitas melalui proses generalisasi pada interval kedalaman yang tidak memiliki sampel batuan core.

Sebagai reservoar pasir serpihan (shaly-sand) Formasi Talang Akar perlu dilakukan pendekatan tipe batuan (rock type), pendekatan ini digunakan dalam mencari hubungan korelasi antara porositas 
dan permeabilitas serta ukuran pore throat radius, sehingga dapat diprediksi unit batuan pada daerah penelitian dan dapat menggambarkan kualitas dari suatu reservoar. Dengan mengetahui kualitas dari setiap reservoar, maka kemampuan reservoar (reservoir performance) dapat digambarkan melalui kurva SMLP (Stratigraphic modified Lorenz Plot). Dimana, penggunaan kurva SMLP (Stratigraphic modified Lorenz Plot) dapat membantu dalam mengetahui zona-zona reservoar yang layak diproduksi atau tidak berdasarkan nilai properti fisika batuan (porositas, pemeabilitas, saturasi).

Berdasarkan permasalahan tersebut, maka penulis tertarik untuk melakukan penelitian ini, diperkuat dengan penelitian yang telah dilakukan oleh Amaefule dkk, (1993) mengenai metode kompilasi rock type dan Syarif dkk, (2015) mengenai pengaruh kehadiran mineral lempung dalam suatu reservoar, penelitian ini amat penting untuk dilakukan, karena dengan adanya penelitian ini kualitas reservoar pasir serpihan dan tingkat produktifitasnya dapat diketahui dengan memperhitungkan berbagai aspek properti petrofisika.

\section{TINJAUAN PUSTAKA}

Daerah penelitian berada di Cekungan Jawa Barat Utara, SubCekungan Arjuna (Gambar 1) yang merupakan cekungan busur belakang yang berkembang sepanjang vulkanik Jawa, yang terbentuk karena adanya aktivitas Tektonik strike-slip. Penelitian ini terfokus pada Formasi Talang Akar yang terbentuk pada masa Oligosen-Miosen Awal, terbagi menjadi 2 bagian yakni Talang Akar Delta dan Marin, dominasi litologi formasi ini berupa endapan batubara delta, batu pasir, batu serpih dan batu gamping. Kehadiran mineral lempung/shale pada formasi ini menjadikan Talang Akar sebagai reservoar shaly sand tempat terakumulasinya hidrokarbon minyak dan gas, sedagkan batuan serpih dikenal sebagai batuan induk, pembentuk hidrokarbon (Noble dkk, 1997). Stratigrafi daerah penelitian ditunjukkan pada Gambar 2.

\section{TEORI DASAR}

\subsection{Pengertian Dasar Well Logging}

Logging merupakan metode pengukuran besaran-besaran fisik batuan terhadap kedalaman lubang bor. Sesuai dengan tujuan logging yaitu menentukan besaran-besaran fisik batuan maka dasar dari logging itu sendiri adalah sifat-sifat fisik atau petrofisik dari batuan (Harsono, 1997).

\subsection{Properti Petrofisika}

Properti batuan yang dihitung pada penelitian ini yaitu:

\section{a. Vsh}

Dimana:

$$
\mathrm{I}_{\mathrm{GR}}=\frac{\mathrm{GR}-\mathrm{GR}_{\mathrm{cn}}}{\mathrm{GR}_{\mathrm{sh}}-\mathrm{GR}_{\mathrm{cn}}}
$$

IGR : shale gamma ray Index

GR : gamma ray log respon $(\mathrm{v} / \mathrm{v})$

GRcn : clean GR log (GRMin) (v/v)

GRsh : shale GR log (GR Max) (v/v)

\section{b. Porositas}

Terdiri dari porositas total dan porositas efektif.

$$
\begin{aligned}
\Phi_{\mathrm{t}} & =\frac{\rho_{\mathrm{ma}}-\rho_{\mathrm{b}}}{\rho_{\mathrm{ma}}-\rho_{\mathrm{f}}} \\
\text { PHIE }= & \text { PHIT }-\mathrm{V}_{\text {sh }}
\end{aligned}
$$

Dimana:

$\Phi_{\text {total }} \quad$ : Total porositas (v/v) 


$$
\begin{array}{ll}
\rho \mathrm{\rho ma} & : \text { Density matriks }(\mathrm{gr} / \mathrm{cc}) \\
\rho \mathrm{\rho b} & : \text { bulk density }(\mathrm{gr} / \mathrm{cc}) \\
\rho \mathrm{\rho f} & : \text { Densitas fluida dari log } \\
& \text { header }(\mathrm{gr} / \mathrm{cc}) \\
\text { PHIT } & : \text { Total porositas }(\mathrm{v} / \mathrm{v}) \\
\mathrm{PHIE} & : \text { porositas efektif(v/v) } \\
\mathrm{Vsh} & : \text { Volume shale }(\mathrm{v} / \mathrm{v})
\end{array}
$$

\section{c. Sw Dual Water}

Karena di dalam reservoar fluida yang mengisi mendapat pengaruh dari lempung maka efek kehadiran lempung harus dihilangkan dengan menghitung nilai saturasi efektifnya.

$$
\begin{aligned}
& \mathrm{Cw}_{\mathrm{e}}=\mathrm{Cw}_{\mathrm{f}}\left(1-S w_{\mathrm{b}}\right)+\mathrm{Cw}_{\mathrm{b}} \cdot S w_{\mathrm{b}} \\
& S w_{\mathrm{t}}=\frac{1}{\emptyset t^{2}} \sqrt{\frac{R w e}{R t}} \\
& S w_{\mathrm{e}}=\frac{S w t-S w \mathrm{~b}}{1-S w b}
\end{aligned}
$$

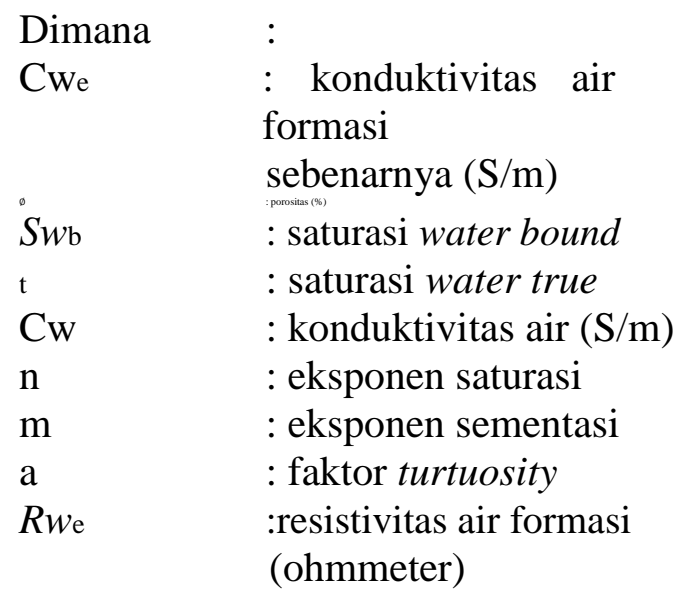

\section{d. Permeabilitas}

Merupakan kemampuan batuan dalam mengalirkan fluida. Yang juga berkiatan dengan flow capacity. Dalam penelitian ini niai diperoleh dari hasil propagasi data.Permeabilitas memiliki satuan $\mathrm{mD}$ (mili Darcy) atau Darcy (Asquith dan Krygowski, 2004)

\section{Multimineral Analisis Untuk Interpretasi Shaly sand}

Formasi Pasir serpihan terdiri dari 3 komponen yaitu Quartz grain (matrix), shale dan fluid.

\section{Metode Winland R35 Dan HFU (Hydraulic Flow Unit)}

\section{a. R35 Winland}

Memformulasikan hubungan antara porositas, permeabilitas, pore throat radius batuan (R35) terhadap profil tekanan kapiler $(\mathrm{Pc})$ injeksi merkuri.

$$
\log (R 35)=0.732+0.588 \log (k)-0.864 \log (\emptyset)
$$

$$
\begin{array}{ll}
\text { Dimana } & : \\
\mathrm{R} 35 & : \text { MICP test } 35 \% \\
\mathrm{~K} & : \text { Permeability }(\mathrm{mD})
\end{array}
$$

\section{b. Metode HFU (Hydraulic Flow Unit)}

Metode HFU didasarkan pada flow unit, pore throat geometry dan parameter geologi (Amaefule dkk, 1993 dalam Shabaninejad dkk, 2011).

$$
\begin{aligned}
& \mathrm{RQI}=0.0314 \times \sqrt{\frac{\mathrm{k}}{\emptyset}} \\
& \mathrm{FZI}=\frac{\mathrm{RQI}}{\emptyset z} \\
& \emptyset z=\frac{\emptyset}{1-\emptyset} \\
& \mathrm{DRT}=\operatorname{Round}[2 \times \ln (\mathrm{FZI})+10.6]
\end{aligned}
$$

\footnotetext{
Dimana :

$\mathrm{k} \quad$ : permeability $(\mathrm{mD})$

$\varnothing \quad$ :porosity $(\%)$

RQI/FZI : reservoir qualityindex

(RQI)

$\emptyset \mathrm{z}$

: normalized porosity (v/v)
}

\section{Stratigraphic Modified Lorenz Plot (SMLP)}

Dengan adanya data rocktype dan 
hydraulic flow unit dari sebuah sumur maka dapat dilakukan modifikasi performa suatu sumur dengan membuat grafik hubungan antara HCPV (hydrocarbon pore volume, flowing capacity dan total storage capacity) terhadap kedalaman (Gunter dkk, 1997).

\section{METODE PENELITIAN}

Adapun data yang digunakan pada penelitian ini yaitu:

\section{Data Las Digital}

Merupakan data wireline logging dari 5 sumur di area Sub-Cekungan Arjuna yakni data sumur IX-13, IX-A1, IX-4, IX7 dan IX-8.

\section{Data Mud Log}

Data mud log merupakan data pengukuran laboratorium yang berisi analisis hidrokarbon pada suatu sumur, data ini tersedia untuk ke-5 sumur

\section{Data completion log dan well header}

Data completion log adalah kurva log hasil pengukuran besertainformasi formasi geologi pada suatu sumur, sedangkan data well header berisi informasi pengukuran mulai dari data koordinat hingga informasi total kedalaman logging, data ini tersedia untuk ke-5 sumur.

\section{Data AnalisisCore}

Data ini terdiri dari data routine core dan special core pengukuran secara konvensional maupun sidewall. Data routine core tersedia untuk 5 sumur sedangkan data special core hanya ada pada sumur IX-A1 dan IX-8.

\section{Data Petrografi, XRD dan Sedimentologi.}

Data-data ini merupakan hasil analisis laboratorium yang digunakan dalam analisis multimineral dan deskripsi tipe batuan (rock type).

\section{Data Marker Geologi}

Data marker geologi berisi informasi batas formasi berdasarkan kedalaman sumur mulai dari start depth hingga bottom depth.

\section{Data DST (Drill steam test)}

Merupakan data informasi produksi dan zona interval perforasi, yang juga digunakan dalam validasi keberadaan zona hidrokarbon berdasarkan oil rate dan gas rate.

Sedangkan alur penelitian terdapat pada Gambar 4.

\section{HASIL DAN PEMBAHASAN}

Berdasarkan Tabel 4, nilai korelasi yang diperoleh jauh lebih baik dibandingkan menggunakan metode R35 Winland, dengan diperolehnya nilai korelasi yang bagus maka diharapkan dapat digunakan dalam analisis lanjut untuk mencari nilai permeabilitas pada interval tanpa batuan core. Dari pendekatan tipe batuan (rocktype) metode HFU didapatkan 8 jenis rocktype, dimana rocktype 7 adalah rocktype yang memiliki sifat aliran paling buruk dan rocktype 14 memiliki sifat aliran paling baik.

\subsection{Identifikasi Lithofacies dan Tipe Batuan (Rocktype)}

\section{- Pembagian lithofacies}

Berdasarkan hasil deskripsi petrografi dan sedimentologi sumur penelitian diperoleh 4 lithofacies yang dibagi berdasarkan sifat fisik batuan, tekstur, struktur, komposisi dan diagenesa yang terjadi.

\section{a. Lithofacies Batubara, Batu Lempung, Batuan Serpih dan Batulanau- Nonreservoar (F1)}


Lithofacies berwarna hitam, abuabu sampai cokelat muda, memiliki kandungan material organik shale yang tinggi. Pada batulempung-lanau sering dijumpai material karbon yang menunjukan lingkungan pengendapan dengan energi rendah-sedang, air payau dan substrat yang berbutir halus-medium. Jenis batuan ini ditunjukkan pada Gambar 7.

\section{b. Lithofacies Batu Pasir Berbutir Sangat Halus (F2)}

Batupasir jenis ini (Gambar 7) memiliki ukuran butir halus dan sortasi baik, didominasi oleh mineral kuarsa, jenis pori berupa intergranular dengan porositas 22-28\%. Masuk kedalam kategori channel sandstone yang masuk kedalam good reservoir.

\section{c. Litofacies Batupasir Sedang-Kasar dengan klastika batulempung dan coal (F3)}

Pada litofasies ini (Gambar 8) struktur sedimen berkembang dengan baik dengan sedikit klastika batulempung sideritik dan batubara berukuran kerikil dengan derajat kebundaran yang cukup baik (subrounded-well rounded). Komposisi penyusun dari facies ini didominasi oleh kuarsa dan mineral kaolinite. Visible porosity berada pada kisaran $15-20 \%$ dan kategori batuan pasir berbutir sedang dengan selingan batubara porositasnya sebesar 6-14\% masuk kedalam poor dan moderate porosity.

\section{d. Lithofacies Batuan Karbonat Argillaceous}

Lithofacies ini (Gambar 8) memiliki sortasi yang baik, berwarna cokelat terang memiliki tekstur wackestone/packstone terdapat pada beberapa sampel di diendapkan pada kondisi shallow marine.

\section{Zona Hidrokarbon Berdasarkan Lumping}

Dari 5 sumur penelitian ditemukan 8 zona hidrokarbon dimana 6 diantaranya tervalidasi dengan data oil rate/gas rate. Diantara zona tersebut adalah sebagai berikut:

Zona hidrokarbon untuk ke-5 sumur dapat diurutkan dari zona yang memiliki kualitas terbaik hingga terburuk berdasarkan distribusi tipe batuan dan juga kapasitas aliran dalam sebuah chart, seperti pada Gambar 12.

Jika ditabulasikan maka Ranking zona reservoar dapat dilihat pada Tabel 3. Performa dari sebuah reservoar juga dapat diidentifikasi menggunakan kurva SMLP dengan menganalisis nilai properti porositas dan permeabilitas, dengan menggunakan kurva ini maka dapat ditetukan juga zona-zona yang layak untuk diproduksi maupun tidak. Kurva ini akan menunjukkan respon yang signifikan apabila dalam sebuah reservoar terdapat kontak air dan adanya indikasi tight reservoar. Dari ke- 8 reservoar yang ditemukan adanya kontak air pada sumur IX-13 (Gambar 9) dan sumur IX-A1 Zona Fn-60 (Gambar 10), sedangkan zona tight reservoar terdapat pada Sumur IX-8 Zona Fn-62C (Gambar 11). 


\section{KESIMPULAN DAN SARAN}

\subsection{Kesimpulan}

Adapun kesimpulan dari penelitian ini adalah sebagai berikut:

1. Dari 5 sumur yang dilakukan analisis ditemukan 8 zona hidrokarbon, 6 diantaranya tervalidasi oleh data DST (Drill Steam Test).

2. Metode tipe batuan (rock type) yang digunakan pada penelitian ini adalah metode HFU (Hydraulic Flow Unit), karena koefisien korelasi antara porositas dan permeabilitas $>0,75$.

3. Tipe batuan (rocktype) yang paling dominan pada penelitian ini yaitu rocktype 12 dengan jenis pori yaitu mesopori.

4. Kualitas yang baik dari ke-8 reservoar

hidrokarbon ditunjukkan dengan semakin besarnya laju aliran fluida dan juga kapasitas total storage. Kurva

SMLP menggambarkan keadaan reservoar yang dapat digunakan untuk penentuan zona perforasi maupun zona produksi.

\subsection{Saran}

Dibutuhkan data core lainnya seperti data MICP (tekanan kapiler dan wetting phase saturation) pada interval litologi sandstone agar dapat dihubungkan dengan jenis rocktype yang diperoleh dan dapat dilakukan validasi menggunakan persamaan J-function.

\section{DAFTAR PUSTAKA}

Archie, G.E., 1941, The electrical resistivity $\log$ as determining some characteristics, Transactions of the American Institute of Mining, Metallurgical and Petroleum Engineers 146, 54-62.

Amaefule, J.O., Altunbay, M., Tiab, D., dan Keelan, D.K.,1993, Enchanced Reservoir Description: Using Core and Log Data to Identify Hydraulic (Flow) Unit and Predict Permeability in Uncored Interval/well, SPE 26436, Proceeding SPE Annual Technical and Exhibition in Houston, Texas.

Cannon, D.E., dan Coates, G.R., 1990, "Applying Mineral Knowledge to StandardLog Interpretation", $A A P G$ journal.

Chiceng, X.U., 2012, Rock Classification in Carbonate Reservoirs Based on Static and Dynamic Petrophysical Properties Estimated from Conventional Well Logs, Proceeding SPEAnnual Technical Exhibition in Houston, Texas.

Doveton, J H., 1986, Log Analysis of Subsurface Geology, John Wiley andSonsInc, USA.

Glover. P., 2010, "Petrophysics Msc Petroleum Geology", Departemen Geology dan Petroleum, University of Aberdeen, UK.

Gunter, G. W., Amoco, EPTG., dan Finneran, J. M., 1997, Early Determination of Reservoir Flow

Units Using and Integrated Petrophysical Method, SPE 38679, Proceeding SPE Annual Technical and Exhibition in Houston, Texas.

Herbudiyanto. S., 2016, Geologi Regional Pertamina Versi 2, PT. PHE ONWJ, Jakarta. 
Harsono. A., 1997, Pengantar Evaluasi Log, Schlumberger Data Services, Jakarta.

Herdiansyah, F., Abdurrokhim, A., dan Syafri, I., 2016, Bulletin of Scientific ContributionLow

\begin{tabular}{lcc} 
Resistivity & Zone & Pada \\
Reservoir & Batupasir & Formasi \\
Cibulakan & Atas & Cekungan \\
JawaBarat & \multicolumn{2}{c}{ Utara, Teknik }
\end{tabular}

Geologi UniversitasvPadjajaran, Jakarta, Volume 14 No. 1.

Kimminau, S., LaVigne, J., Singer, J., and Wendel, F., 1986, "A Coherent Framework for Developing and Applying Multiple Formation Evaluation Models", $A A P G$ Journal.

Laporan Internal dan PPT PT. PHE ONWJ (2009-2016).

Martin, A.J., Solomon, S.T., Hartmann, D.J., 1997,Characterization of petrophysics flow units in carbonate reservoirs, $A A P G$ Bulletin, page: 734-759.

Noble, R. A., 1997, Differentation of oils from the NW Java Basin into three oil types basedon biomarker composition, Proceedings of an International Conference on Petroleum Systems of SE Asia \& Australia: Indonesian Petroleum Association, p. 585-600.

Shabaninejad, M., dan Haghighi, BM., 2011, "Rock Typing and Generalization of PermeabilityPorosity Relationship For an Iranian Carbonate Gas Reservoir"Society of PetroleumEngineers Paper No. 15089, Annual International Conference and exhibition.

Telford, W M., Geldart, L.P dan Sheriff R. E., 1990, "Applied Geophysics, Secondedition", United State of America: Cambridge University Press. 


\section{LAMPIRAN}

Tabel 1. Tipe Pori Batuan (Martin, 1997)

\begin{tabular}{ll}
\hline Pore Type & Pore Throat(mikron) \\
\hline Megaporous & $>10$ \\
Macroporous & $2.5-10$ \\
Mesoporous & $0.5-2.5$ \\
Microporous & $0.2-0.5$ \\
Nanoporous & $<0.2$ \\
\hline
\end{tabular}

Tabel 2. Persamaan Porositas Permeabilitas dari Metode R35 Winland

\begin{tabular}{cccc}
\multicolumn{4}{c}{$\mathrm{y} \mathrm{R}^{2}{ }^{\mathrm{R} 35}$ Classification } \\
\hline PRT 1 & $\mathrm{y}=0.023 \exp 0.164 \mathrm{x}$ & 0.319 & Nanoporous \\
PRT 2 & $\mathrm{y}=0.139 \exp 0.190 \mathrm{x}$ & 0.725 & Microporous \\
PRT 3 & $\mathrm{y}=2.182 \exp 0.088 \mathrm{x}$ & 0.868 & Mesoporous \\
PRT 4 & $\mathrm{y}=10.49 \exp 0.073 \mathrm{x}$ & 0.64 & Macroporous \\
PRT 5 & $\mathrm{y}=42.02 \exp 0.056 \mathrm{x}$ & 0.221 & Macroporous \\
PRT 6 & $\mathrm{y}=2.130 \operatorname{exp0.205x}$ & 0.535 & Megaporous \\
\hline
\end{tabular}

Tabel 3. Reservoir Performance Rank

\begin{tabular}{cclcc}
\hline Well & $\begin{array}{c}\text { Interval } \\
\text { zone }\end{array}$ & Pore throat & Rocktype & $\begin{array}{c}\text { Flowing } \\
\text { Capacity } \\
\text { result } \\
\text { (mD) }\end{array}$ \\
\hline IX-4 & Fn-61B & macroporous & 12,13 & 14034 \\
& & & 11,12, & \\
IX-A1 & Fn-60 & macroporous & 13 & 7405 \\
& & & 10,11, & \\
IX-4 & Fn-58C & microporous & 12 & 2225 \\
IX-13 & Fn-64 & macroporous & 12,13 & 2068 \\
IX-7 & Fn-58C & macroporous & 11,12 & 1376 \\
& & & $9,10,11$, & \\
IX-A1 & Fn-65 & mesoporous & 12,13 & 977 \\
IX-8 & Fn-62C & microporous & 11,12 & 683 \\
& & & 10,11, & \\
IX-8 & Fn-58C & microporous & 12 & 305 \\
\hline
\end{tabular}

Tabel 4. Persamaan Porositas Permeabilitas dari Metode HFU

\begin{tabular}{|c|c|c|c|c|}
\hline $\begin{array}{c}\text { Rocktyp } \\
e\end{array}$ & $\mathrm{y}$ & $\mathrm{R}^{2}$ & $\begin{array}{c}\text { Pore } \\
\text { throat } \\
\text { radius } \\
\text { (micro } \\
n)\end{array}$ & $\begin{array}{c}\text { Pore } \\
\text { throa } \\
t \\
\text { type }\end{array}$ \\
\hline 7 & $\begin{array}{c}y=0.001^{*} \text { exp30. } \\
90(x)\end{array}$ & 1 & $\begin{array}{c}0.17- \\
0.2\end{array}$ & $\begin{array}{c}\text { Nan } \\
0\end{array}$ \\
\hline 8 & $\begin{array}{c}y=0.011^{*} \text { exp20. } \\
26(x)\end{array}$ & $\begin{array}{c}0.93 \\
6\end{array}$ & $\begin{array}{l}0.2- \\
0.31\end{array}$ & Micr \\
\hline & $y=0.028^{*} \exp 23$ & 0.98 & $0.4-$ & 0 \\
\hline 9 & $\begin{array}{c}89(x) \\
y=0.115^{\star} \exp 19 .\end{array}$ & $\begin{array}{c}7 \\
0.92\end{array}$ & $\begin{array}{l}0.51 \\
0.6-\end{array}$ & \\
\hline 10 & $\begin{array}{c}24(x) \\
y=0.370^{\star} \exp 18\end{array}$ & $\begin{array}{c}6 \\
0.91\end{array}$ & $\begin{array}{l}0.95 \\
1.0\end{array}$ & Mes \\
\hline 11 & $\begin{array}{c}41(x) \\
y=2.091^{*} \exp 15\end{array}$ & $\begin{array}{c}9 \\
0.87\end{array}$ & $\begin{array}{l}1.5 \\
1.6-\end{array}$ & 0 \\
\hline 12 & $\begin{array}{c}70(x) \\
y=4.229^{*} \exp 17 .\end{array}$ & $\begin{array}{c}3 \\
0.76\end{array}$ & $\begin{array}{l}2.5 \\
2.6-\end{array}$ & \\
\hline 13 & $\begin{array}{c}08(x) \\
y=6.251^{*} \exp 18\end{array}$ & $\begin{array}{c}7 \\
0.75\end{array}$ & $\begin{array}{l}4.1 \\
4.2-\end{array}$ & $\begin{array}{c}\text { makr } \\
0\end{array}$ \\
\hline 14 & $2(x)$ & 1 & 6.2 & \\
\hline
\end{tabular}

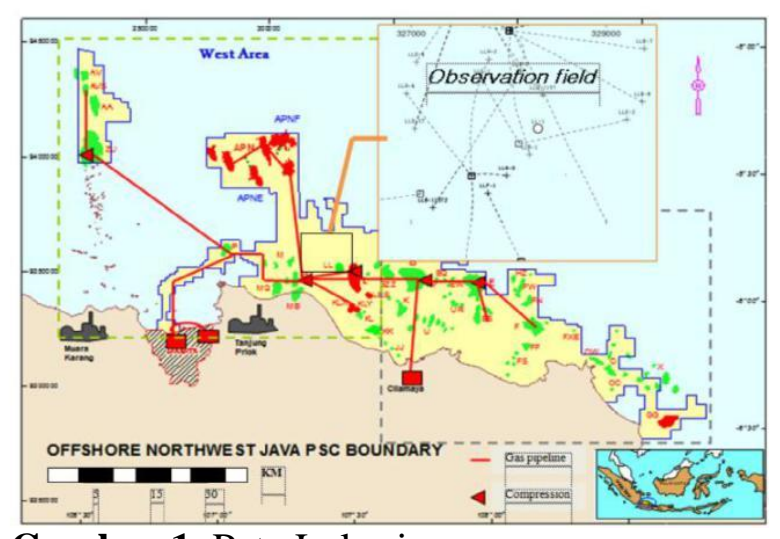

Gambar 1. Peta Lokasi

Penelitian(Laporan Internal PHE ONWJ)

OFFSHORE NORTHWEST JAVA STRATIGRAPHY

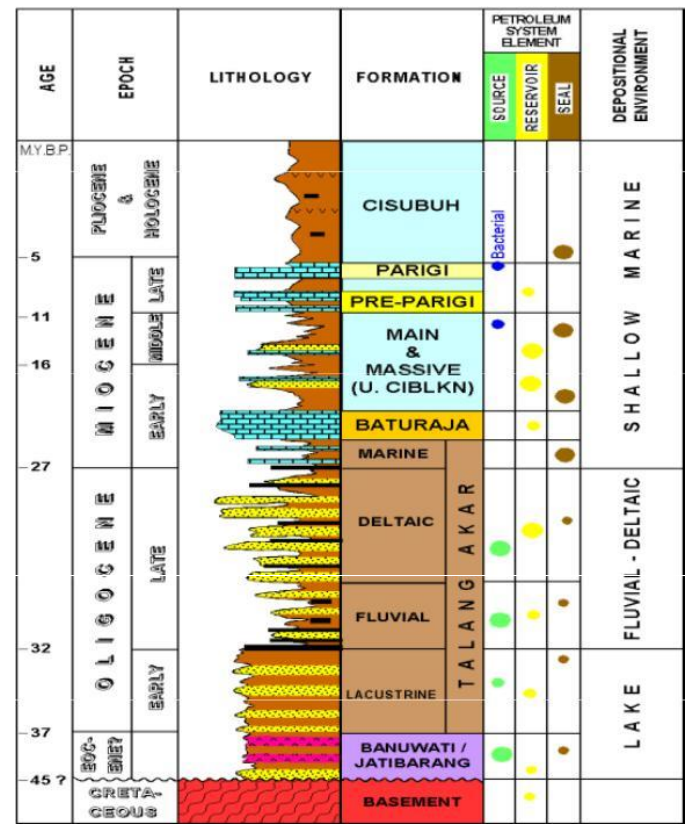

Gambar 2.Kolom Stratigrafi Cekungan Jawa Barat Utara (Herbudiyanto dalam Geologi Regional PHE ONWJ Versi II, 2016).

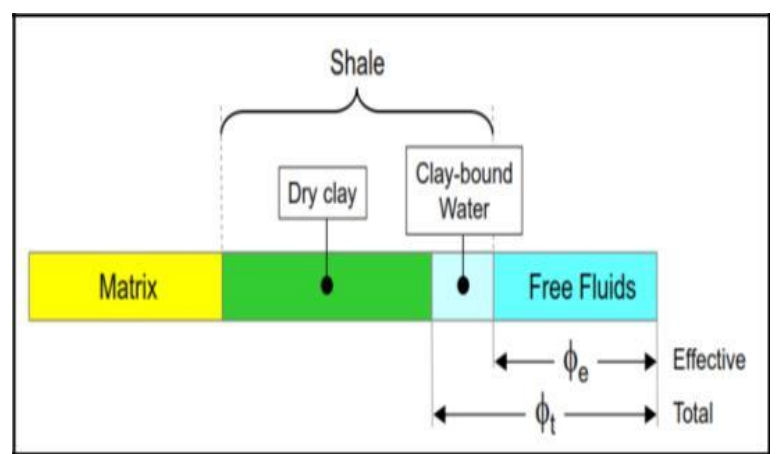

Gambar 3. Model Reservoar Pasir 


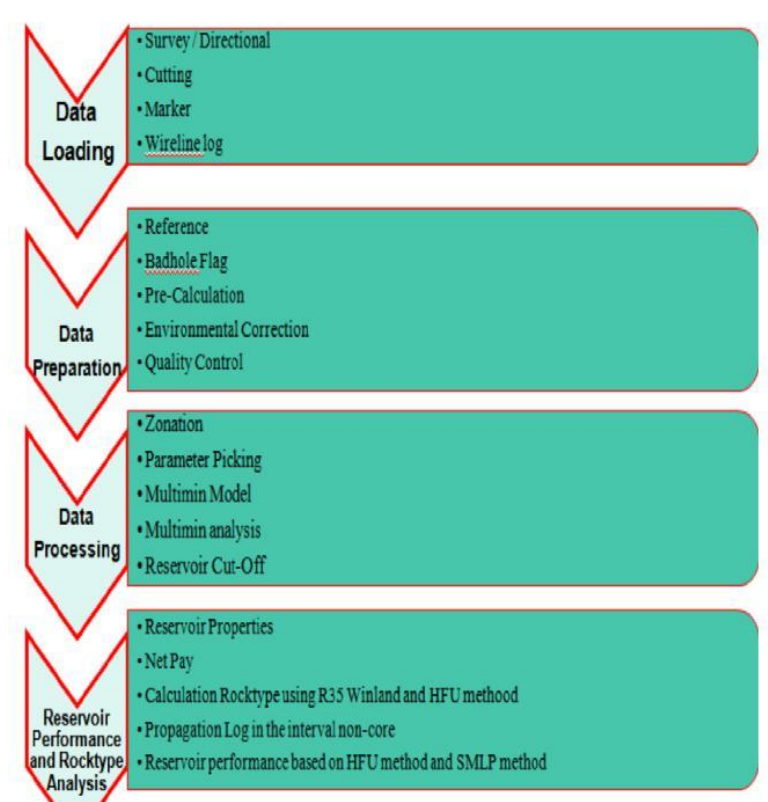

Gambar 4. Prosedur Penelitian

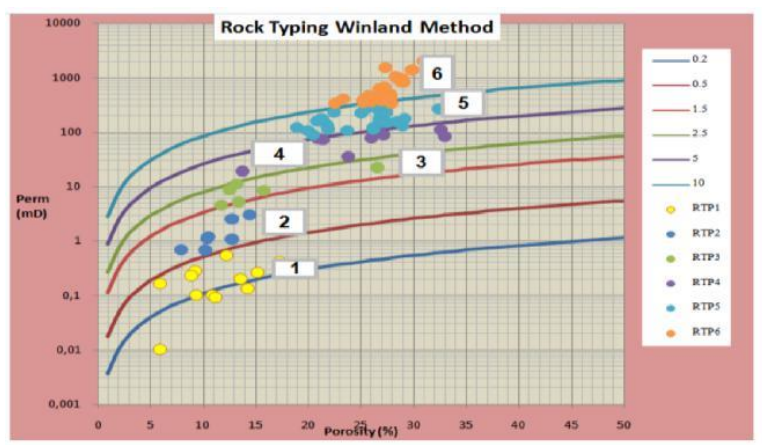

Gambar 5. Distribusi Tipe Batuan

BerdasarkanMetode R35 Winland

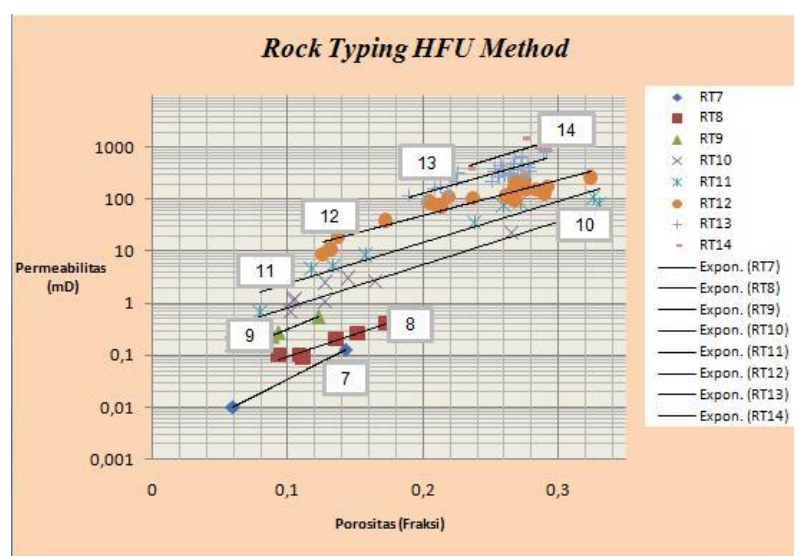

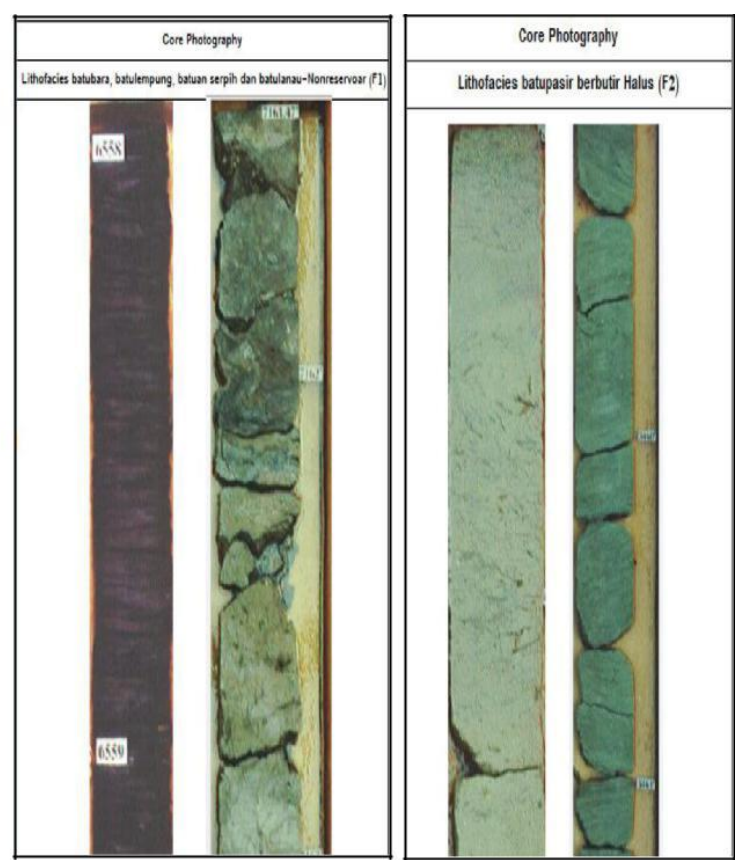

Gambar 7. Lithofacies F1 (kiri) dan F2 (kanan)

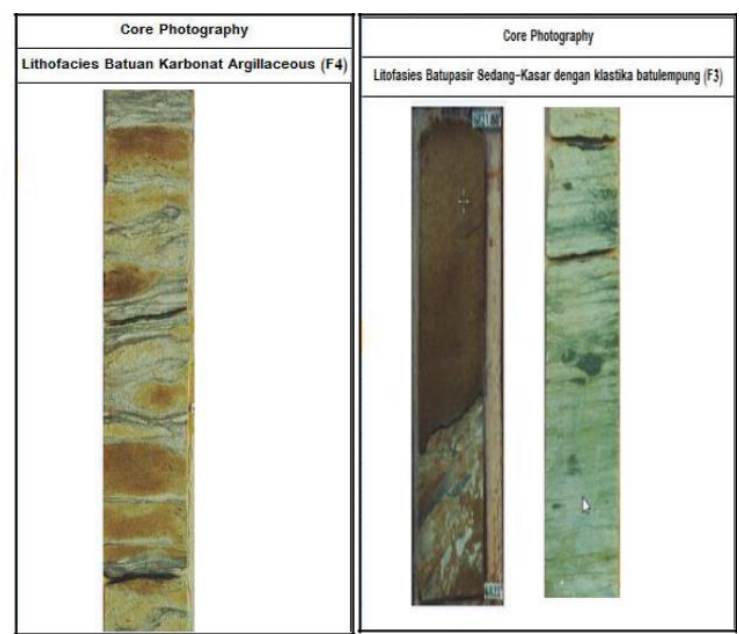

Gambar 8. Lithofacies F3 (kiri) dan F4 (kanan)

Gambar 6. Distribusi Tipe Batuan

Berdasarkan Metode HFU 


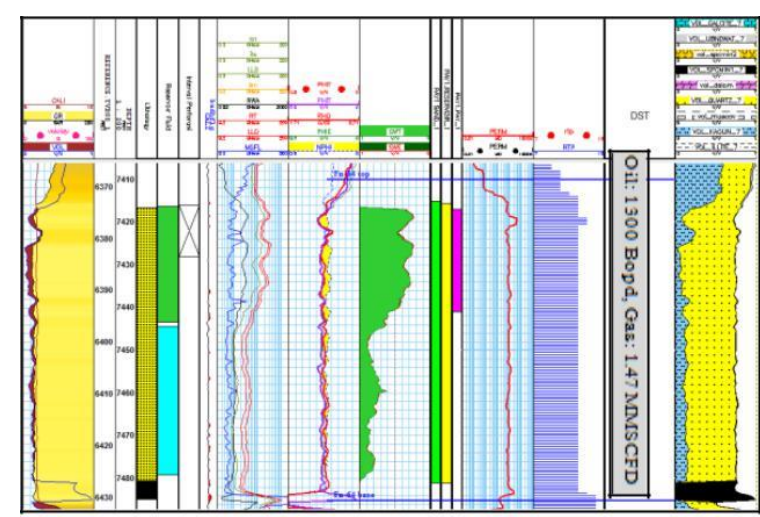

Gambar 9. Hasil Analisis Petrofisika sumur IX-13

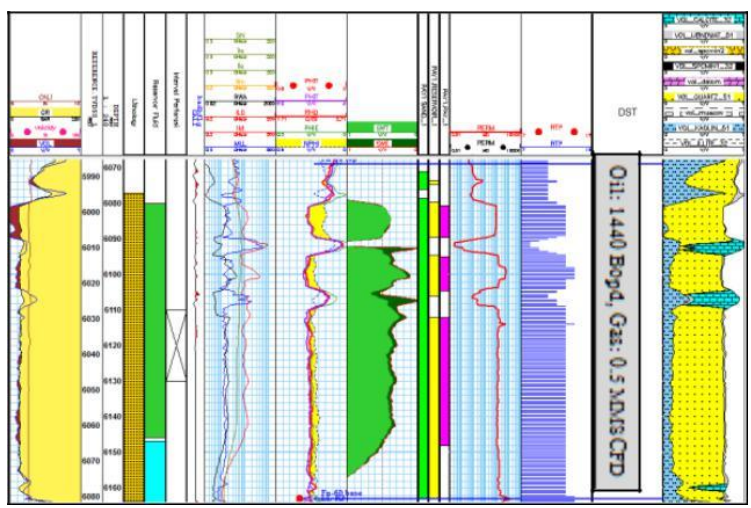

Gambar 10. Hasil Analisis Petrofisika sumur IX-A1 Zona Fn-60

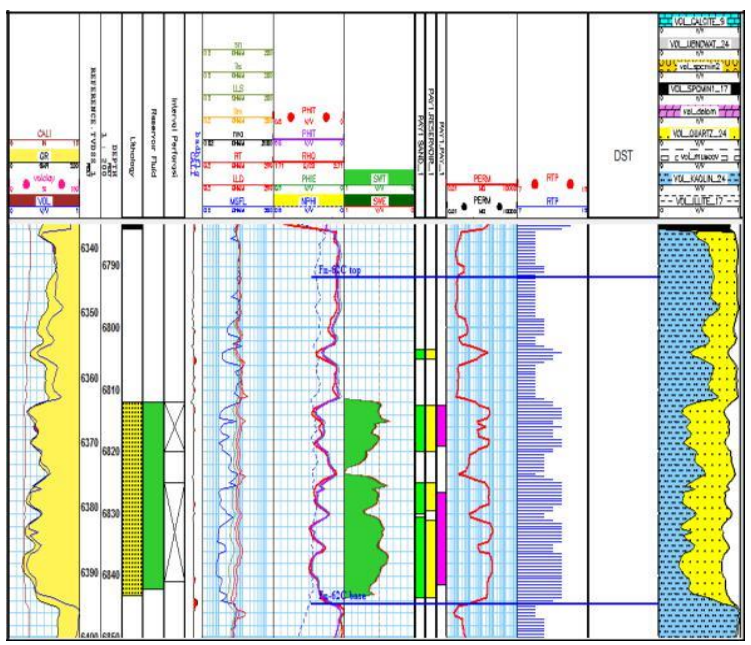

Gambar 11. Hasil Analisis Petrofisika sumur IX-8 Zona Fn-62C

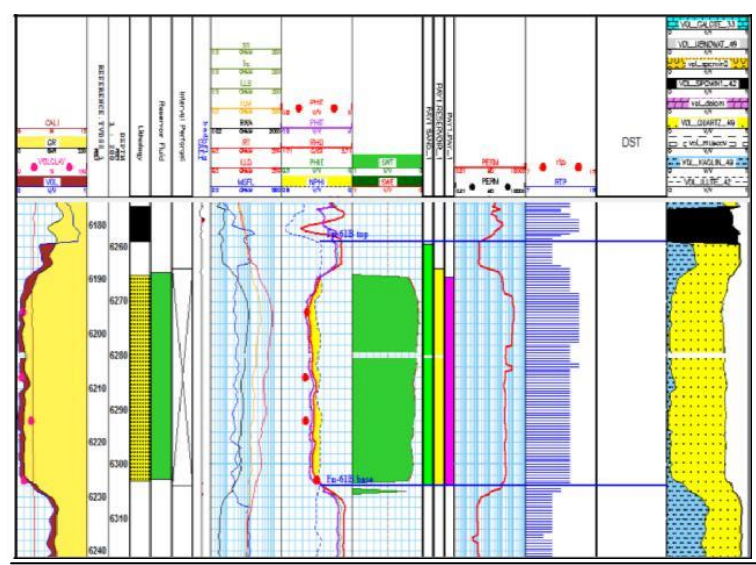

Gambar 12. Hasil Analisis Petrofisika sumur IX-4 Zona Fn-61B

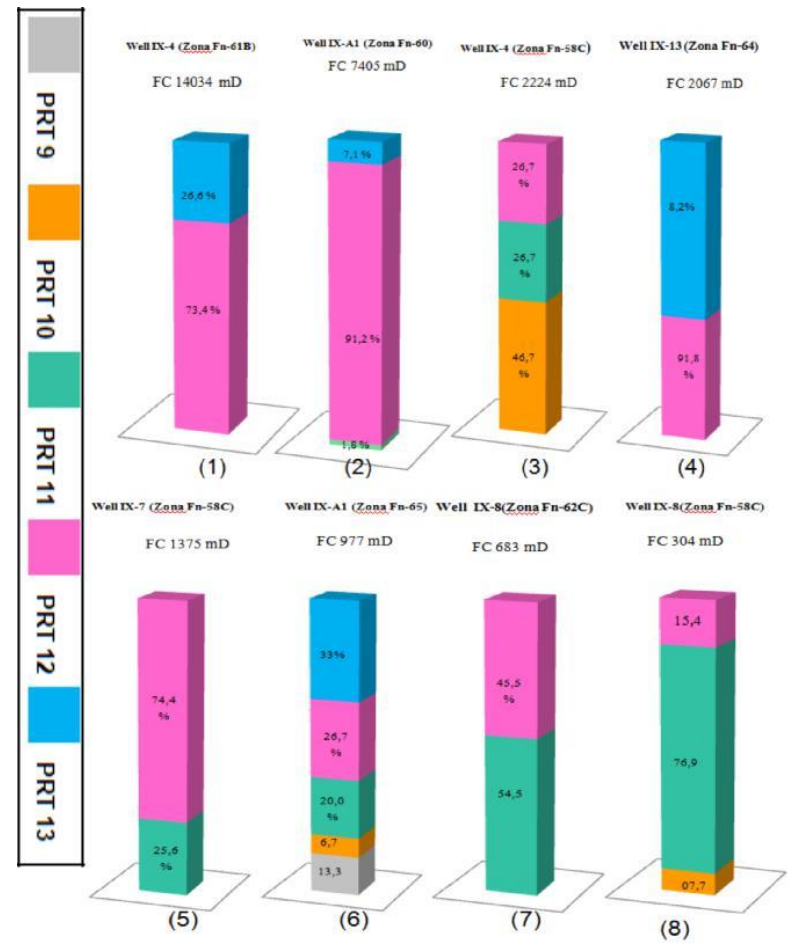

Gambar 13. Reservoir Distribution Chart 


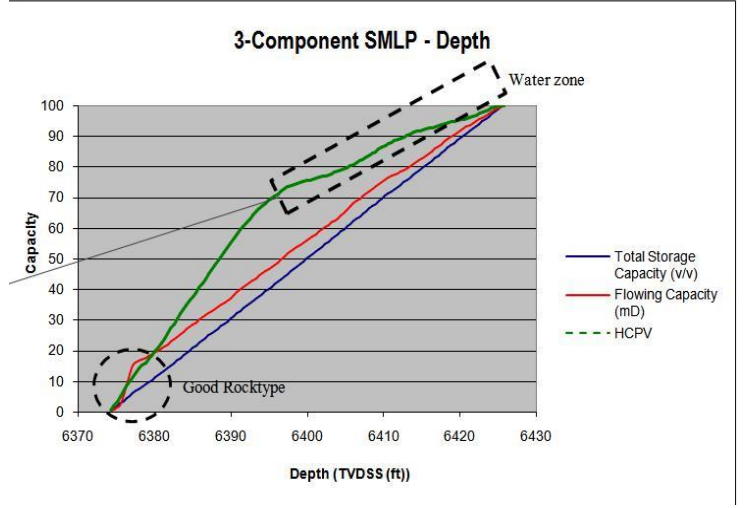

Gambar 14. Grafik SMLP sumur IX-13

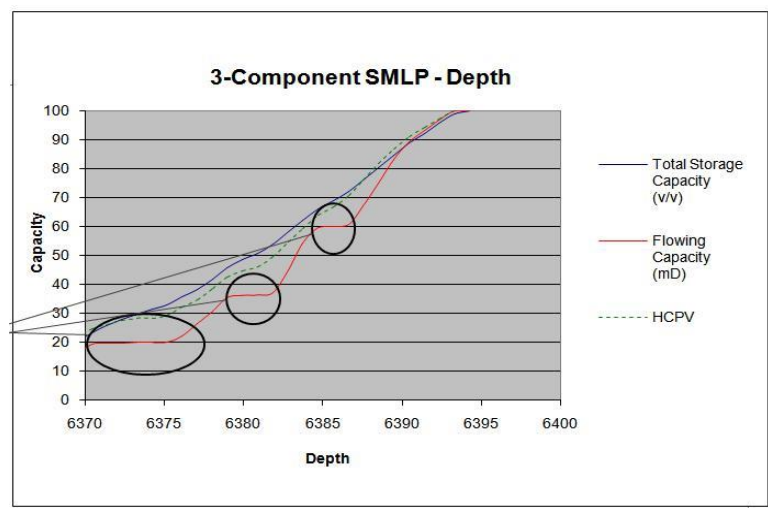

Gambar 15. Grafik SMLP sumur IX-8

Zona

Fn-62C

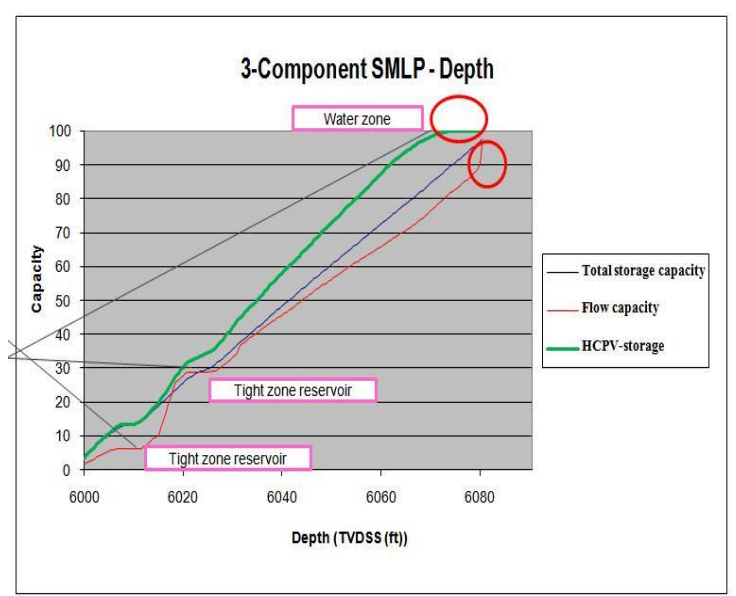

Gambar 16. Grafik SMLP sumur IX-A1

Zona Fn-60 